\title{
Brown tumours: widespread involvement of multiple maxillofacial bones and cervical spine
}

\author{
Tej Gadhia, ${ }^{1}$ Oluyori Kutulola Adegun, ${ }^{2}$ Farida Fortune ${ }^{2}$
}

${ }^{1}$ Department of Oral Medicine, Dental Institute, Royal London Hospital, Barts Health NHS Trust, London, UK ${ }^{2}$ Centre for Clinical and Diagnostic Oral Sciences, Institute of Dentistry, Barts and The London School of Medicine and Dentistry, Queen Mary University of London, London, UK

\section{Correspondence to} Professor Farida Fortune, f.fortune@qmul.ac.uk

Accepted 26 October 2014

\section{DESCRIPTION}

Brown tumours are sequelae of abnormal bone metabolism in hyperparathyroidism. ${ }^{1}$ Primary, secondary and tertiary hyperparathyroidism are causative with most cases of the secondary type. ${ }^{2}{ }^{3}$ This article highlights Brown tumours of bones rarely reported in literature.

We report a case of a 34-year-old woman with difficulty in eating and speaking as a result of a reduced mouth space. Medical history revealed end-stage renal disease for which she underwent haemodialysis three times a week. Physical examination showed firm bony expansions on both maxillary buccal shelves, anterior palate, and labial and lingual plates of the mandible. CT imaging of the head and neck demonstrated widespread groundglass appearance of the dental arches, facial bones and cervical spine (figures 1 and 2). In the maxilla, multilocular and expansile lesions involving the right and left buccal shelves are seen, with the latter more prominent (figure 1A). In the mandible, multiple destructive lesions (figure 1C), bony expansions of the labial and lingual plates and prominent anterior interdental spacing (figure $1 \mathrm{~B}, \mathrm{C}$ ) were observed. Loss of lamina dura around the lower canine root and a moth-eaten appearance in the gonial area are shown in figure 2B. Unusually, multiple concurrent osteolytic lesions of the zygomatic complexes (figure $2 \mathrm{~A}, \mathrm{C}$ ) and cervical spine (figure 2B, C), both infrequently reported, were also identified. Biochemical investigations showed raised urea, creatinine, alkaline phosphatase and serum parathyroid hormone $(2007 \mathrm{pg} / \mathrm{mL}$; normal 16-69 pg/mL). These findings are consistent with Brown tumours in hyperparathyroidism secondary to end-stage renal disease. ${ }^{2}$

\section{Learning points}

- Brown tumours can simultaneously affect multiple bones of the dentoalveolar, maxillofacial area and the cervical spine.

- Clinicians should be familiar with the characteristic radiographic presentations in patients with hyperparathyroidism and be aware that the lesions may affect large areas of bone.

- Lesions within the facial skeleton may cause narrowing of foramina and the oral cavity.

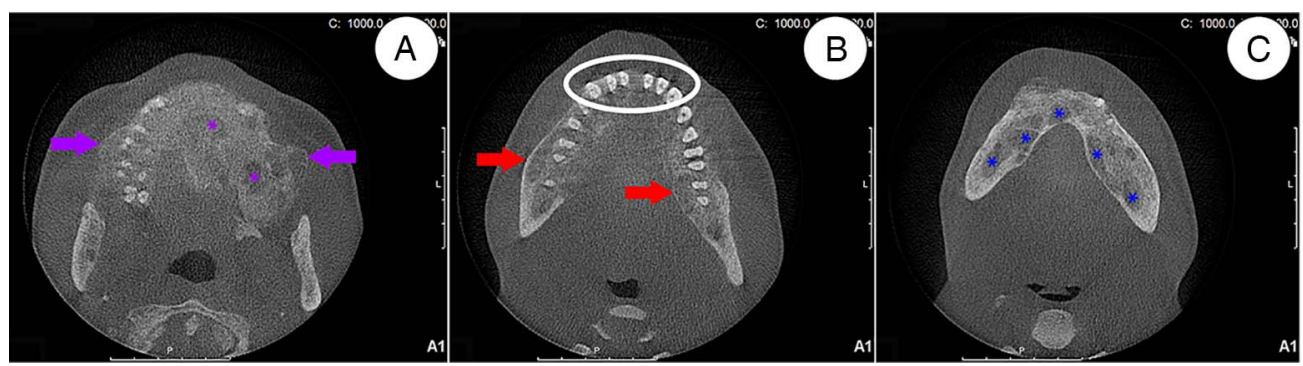

Figure 1 Axial CT images of the dental arches showing (A) bony lumps on the maxillary buccal shelf areas with the left side most severely affected (purple arrows) and lytic areas in the palate (purple asterisks); (B) bony expansion of the mandible (red arrows) and prominent interdental spaces anteriorly (white circle) and (C) multiple osteolytic lesions of the whole mandible (dark blue asterisks).


Figure 2 (A) Coronal CT image showing widespread involvement of multiple bones of the maxillofacial area (light blue asterisks). (B) Sagittal CT image showing loss of the lamina dura around the lower canine root (yellow arrow), prominent osteolytic lesions in gonial area (yellow asterisks) and cervical spine (dark blue arrows). (C) Axial CT images with osteolytic lesions involving both zygomatic complexes and the cervical spine (green asterisks). 
Contributors TG, OKA and FF contributed to the patient care and drafting of the article.

Competing interests None.

Patient consent Obtained.

Provenance and peer review Not commissioned; externally peer reviewed.

\section{REFERENCES}

1 Arora A, Tolley N, Tuttle RM. Practical manual of thyroid and parathyroid disease. Oxford: Wiley-Blackwell, 2010.

2 Fraser WD. Hyperparathyroidism. Lancet 2009;374:145-58.

3 Selvi F, Cakarer $S$, Tanakol $R$, et al. Brown tumour of the maxilla and mandible: a rare complication of tertiary hyperparathyroidism. Dentomaxillofac Radiol 2009;38:53-8.

Copyright 2014 BMJ Publishing Group. All rights reserved. For permission to reuse any of this content visit http://group.bmj.com/group/rights-licensing/permissions.

BMJ Case Report Fellows may re-use this article for personal use and teaching without any further permission.

Become a Fellow of BMJ Case Reports today and you can:

- Submit as many cases as you like

- Enjoy fast sympathetic peer review and rapid publication of accepted articles

- Access all the published articles

- Re-use any of the published material for personal use and teaching without further permission

For information on Institutional Fellowships contact consortiasales@bmjgroup.com

Visit casereports.bmj.com for more articles like this and to become a Fellow 